\title{
Analysis of Economic Efficiency and Competitiveness of the Rice Production Systems of Pakistan's Punjab
}

\author{
Waqar Akhtar, Muhammad Sharif and Nadeem Akmal*
}

\begin{abstract}
The Policy Analysis Matrix (PAM) methodology was used to determine the level of economic efficiency and competitiveness in the production of rice crops in Pakistan's Punjab. The methodology was also used to assess the effect of policy intervention on the production of Basmati and IRRI rice crops. The results indicate that an expansion of the production of Basmati rice can lead to an increase in exports. The production of IRRI in Pakistan's Punjab is characterized by a lack of economic efficiency implying inefficient use of resources to produce the commodity. On the other hand, both Basmati and IRRI rice production in the Punjab demonstrate a lack of competitiveness at the farm level for the period under analysis. The analysis shows that the prevailing incentive structure affected farmers negatively. A negative divergence between private and social profits implies that the net effect of policy intervention is to reduce the farm level profitability of both rice production systems in Punjab. The results highlight the need for removing existing policy distortions in the structure of economic incentives to enhance economic efficiency and to attain farm level competitiveness in rice production.
\end{abstract}

\section{Introduction}

Agriculture is the mainstay of Pakistan's economy. It also contributes substantially to Pakistan's exports and is an important food cash crop. It is the second largest agricultural export item of the country and accounts for 6.1 percent of the total value added in agriculture and 1.3 percent of GDP. In Pakistan's Punjab, basmati and IRRI rice are two varieties cultivated, consumed and exported. Basmati has a lower yield and a higher production cost than IRRI rice, but these are offset by higher prices. Using guaranteed price supports for both varieties, the government encourages farmers to

\footnotetext{
${ }^{*}$ The authors respectively are Assistant Scientific Officer, Chief Scientific Officer and Scientific Officer, Social Sciences Institute (SSI), National Agricultural Research Centre (NARC), Islamabad.
} 
produce exportable surpluses, particularly of Basmati, where Pakistan has a comparative advantage and is the dominant supplier of the world's premier non- gluteus long grain aromatic rice in the international market (Davidson, 1996).

As with most agricultural commodity markets, the rice market also suffers from the cobweb phenomenon, where price fluctuations are caused by the time lag between making the decision to cultivate the crop and the ultimate selling of the crop. To decrease the risk faced by farmers from fluctuating prices, the government has set support prices for various varieties of rice (Ahmed, et al., 2000).

The Agreement on Agriculture (AOA) of the World Trade Organization (WTO) has set targets for future world trade such as trade liberalization, non-intervention by governments and elimination of trade barriers. This would greatly improve world trade volumes and benefit the countries following free trade regimes, since trade is beneficial to those countries which have a comparative advantage in a particular commodity and is mutually advantageous to countries importing cheap raw materials. The literature shows that Pakistan is likely to benefit more in producing commodities where there is a comparative advantage than any developing country under full reform conditions (Hussain et al., 2006).

Governments intervene in agriculture and influence output and input markets. Frequently, the measures used include tariffs, quotas and subsidies designed for trade protection or enhancement, and price supports designed to increase farm income. The impact of policy distortions is particularly evident when Pakistan's high level of agricultural disprotection is compared with other countries that pursued different policies (Faruqee 1995). Faruqee (1995) quoted the example of high performing East Asian economies which had lower levels of disprotection of agriculture. He further argued that in the presence of past pricing distortions, output losses were huge in Pakistan, to the tune of 10 percent a year for cotton and 6 percent a year for wheat for the mid-1980s (Faruqee 1995). He also reported that Pakistan has a comparative advantage in the production of Basmati rice, wheat and cotton, whereas coarse rice and sunflower production are marginally inefficient. Analyses of resource use efficiency through DRC and incentives in production were used to gain insight into the economic efficiency and the effects of policy interventions in the rice production systems of Pakistan's Punjab. The use of economic efficiency analysis through comparative advantage deals not only with on-farm production but incorporates whole commodity systems and thus provides an analysis of the entire commodity chain (Slinger, 1997). 
In most developing countries with distorted markets and trade barriers, domestic resources are costlier than traded inputs and distortions lead to the misallocation of resources (Gonzales, 1984, and Gonzales et a1., 1993). In developing countries, due to distortions in factors and output markets, externalities and government policy interventions, social or economic profitability deviates from private profitability. This allows a wide gap between competitiveness and comparative advantage, and failure to measure and account for market distortions might lead to biases. Comparative advantage indicates whether it is economically advantageous for a country to expand production and trade of a specific commodity, while competitiveness indicates private commercial performance of individual firms (Warr, 1994). Warr further argued that the two concepts are not the same and any attempt to portray them as being the same, or at least similar, is misleading. In this situation a crop can be profitable for farmers but its production may not be an efficient use of national resources and vice versa. The divergence between private and social values stem from the varying interest of the growers and society (Khan, 2001).

\section{Research Methodology}

\subsection{Nature and Source of data}

This study is based on secondary data from different national sources. The main sources of the data were the Agricultural Prices Commission (APCOM), Economic Advisors Wing, Finance Division, Economic Wing MINFAL, Central Board of Revenue (CBR) and National Fertilizer Development Centre (NFDC). Some specific documents were Support Price Policy for Rice (paddy), Agricultural Statistics of Pakistan, CBR Yearbook, and Pakistan Fertilizer Related Statistics (various issues). The most important source of data was Support Price Policy Reports which contained extensive information on the cost of different operations performed by average farmers including tractor operations, labor usage for different tasks, seed and seed treatment, irrigation, fertilizer expenses, land rent and management charges, etc. They can be grouped categorically as follows: (1) Technical input-output coefficients were used at the farm level (2) Domestic farmgate prices (procurement prices adjusted for marketing costs) for output and domestic market prices for inputs and other resources were used (3) International farmgate prices (export/import unit value) for outputs and inputs adjusted for the shadow exchange rate, internal cost of marketing, processing, transport and handling were used. In order to calculate the social prices of non-tradable inputs for this study a standard format was utilized, as suggested by Appleyard (1987). 


\subsection{Method of Analysis}

The method of analysis utilized to measure the economic efficiency and competitiveness of rice production systems was the Policy Analysis Matrix (PAM) (Table-1). This framework was developed by Monke and Pearson (1989), and augmented by recent developments in price distortion analysis by Masters and Winter-Nelson (1995). PAM is a tool that allows us to examine the impact of policy by constructing two enterprise budgets, one valued at market prices and the other valued at social prices. The PAM, once assembled, provides a convenient method of calculating the measure of policy effects and measures of competitiveness and economic efficiency/ comparative advantage. A wide range of government policies have influences on protection/disprotection of agricultural production, which can be measured by using nominal and effective protection rates as indicators. This framework is particularly useful in identifying the appropriate direction of change in policy (Gonzale et al., 1993). In the present study particular attention is given, however, to competitiveness and economic efficiency in domestic resources by using a PAM framework. These methods have the same foundation, but differ in their capacity to interpret the results. Many recent studies have utilized a PAM framework to evaluate competitiveness and comparative advantage and policy effects in Pakistan for different crops, some of which are Salman and Martini (2000), Khan (2001), Khan and Rana (2004). The impact of policy is then assessed as the divergence between private and social valuation. The assessment of competitiveness and economic efficiency of rice crop production at the farmgate level of Pakistan's Punjab was undertaken using the data for the period 1995-96 to 2004-05, and the necessary indicators were derived to explain the private profitability, social profitability and divergence for the entire period.

Table-1: Framework of Policy Analysis Matrix (PAM)

\begin{tabular}{lcccc}
\hline & Revenue & \multicolumn{2}{c}{ Costs } & Profits \\
\hline & & $\begin{array}{c}\text { Tradable } \\
\text { Inputs }\end{array}$ & $\begin{array}{c}\text { Domestic } \\
\text { Factors }\end{array}$ \\
\hline Valued at Private prices & $\mathrm{A}=P_{i d} * Q_{i}$ & $\mathrm{~B}=P_{i d} * Q_{i}$ & $\mathrm{C}=P_{n d} * Q_{n}$ & $\mathrm{D}$ \\
Valued at Social prices & $\mathrm{E}=P_{i b} * Q_{i}$ & $\mathrm{~F}=P_{i b} * Q_{i}$ & $\mathrm{G}=P_{n s} * Q_{n}$ & $\mathrm{H}$ \\
Divergence & $\mathrm{I}$ & $\mathrm{J}$ & $\mathrm{K}$ & $\mathrm{L}$ \\
\hline
\end{tabular}

Source: Based on Monke and Pearson (1989)

Private profit: $\mathrm{D}=A-(B+C)$; Social profit: $\mathrm{H}=\mathrm{E}-(F+G)$; Output transfer: $\mathrm{I}=A-$ $E$; Input transfer: $\mathrm{J}=B-\mathrm{F}$

Factor transfer: $\mathrm{K}=C-\mathrm{G}$, Net policy transfer: $\mathrm{L}=\mathrm{D}-\mathrm{H}$ 
Where: $P_{i d}=$ domestic price of output $i$

$P_{j d}=$ domestic price of tradable input $j$

$P_{i b}=$ international price of output $i$

$P_{j b}=$ international price of tradable input $j$

$P_{n d}=$ market price of non-tradable input $n$

$P_{n s}=$ shadow price of non-tradable input $n$

$Q_{i}=$ quantity of output

$Q_{j}=$ quantity of tradable input.

$Q_{n}=$ quantity of non-tradable input.

The indicator in the first row of Table-1 provides a measure of private profitability (D), or competitiveness, and is defined as the difference between observed revenue $(A)$ and costs $(B+C)$. Private profitability demonstrates the competitiveness of the agricultural system, given current technologies, prices for inputs and outputs, and policy interventions and market failures. The second row of the matrix calculates the measure of social profitability $(\mathrm{H})$ defined as the difference between social revenue (E) and costs $(F+G)$. Social profitability measures economic efficiency/ comparative advantage of the agricultural system.

\subsection{Ratio Indicators}

The PAM framework can also be used to calculate important indicators for policy analysis. The computation of the following measures for Pakistan were established by Appleyard (1987), Salman and Martini (2000), Chaudhry and Kayani (1999):

\section{a) Nominal Protection Coefficient on Output (NPCO)}

This ratio shows the extent to which domestic prices for output differ from international reference prices. If NPCO is greater than 1 , the domestic farm gate price is greater than the international price of output and thus the system receives protection. On the contrary, if NPCO is less than 1 , the system is disprotected by policy. NPCO is expressed as:

$$
\mathrm{NPCO}=(\mathrm{A}) /(\mathrm{E})=\left(P_{i d} * Q_{i}\right) /\left(P_{i b} * Q_{i}\right)
$$




\section{b) Nominal Protection Coefficient on Input (NPCD)}

This ratio shows how much domestic prices for tradable inputs differ from their social prices. If NPCI exceeds 1 , the domestic input cost is greater than the comparable world prices and thus the system is taxed by policy. If NPCI is less than 1 , the system is subsidized by policy. Using the PAM framework, NPCI is derived as:

$$
\mathrm{NPCI}=(\mathrm{B}) /(\mathrm{F})=\left(P_{j d} * Q_{j}\right) /\left(P_{j b} * Q_{j}\right)
$$

\section{c) Effective Protection Coefficient (EPC)}

EPC is the ratio of value added in private prices (A-B) to value added in social prices (E-F). An EPC value of greater than 1 suggests that government policies provide positive incentives to producers, while values less than 1 indicate that producers are disprotected through policy interventions on value added. EPC is expressed as:

$$
\mathrm{EPC}=(\mathrm{A}-\mathrm{B}) /(\mathrm{E}-\mathrm{F})=\left\{\left(P_{i d} * Q_{i}\right)-\left(P_{j d} * Q_{j}\right)\right\} /\left\{\left(P_{i b} * Q_{i}\right)-\left(P_{j b} * Q_{j}\right)\right\}
$$

\section{d) Domestic Resource Cost (DRC) Ratio}

The DRC was brought into common use by Bruno (1972) specifically for the purpose of measuring comparative advantage. According to Bruno (1972) and Krueger (1966 and 1972), the economic efficiency in domestic resource use of a commodity system can be assessed by using this ratio. Since minimizing the DRC is equivalent to maximizing social profits, if the DRC ratio is less than 1 , the system uses domestic resources efficiently. If the DRC ratio is greater than 1 , then the system shows inefficiency in domestic resource use and possesses a comparative disadvantage. The method of calculating the DRC ratio in the PAM framework is given as:

$$
\mathrm{DRC}=(\mathrm{G}) /(\mathrm{E}-\mathrm{F})=\left(P_{n s} * Q_{n}\right) /\left\{\left(P_{i b} * Q_{i}\right)-\left(P_{j b} * Q_{j}\right)\right\}
$$

\section{e) Private Cost Ratio (PCR)}

PCR is the ratio of factor costs $(\mathrm{C})$ to value added in private prices (A-B). This ratio measures the competitiveness of a commodity system at the farm level. The system is competitive if the PCR is less than 1. Using the PAM framework the PCR can be expressed as:

$$
\mathrm{PCR}=(\mathrm{C}) /(\mathrm{A}-\mathrm{B})=\left(P_{n d} * Q_{n}\right) /\left\{\left(P_{i d} * Q_{i}\right)-\left(P_{j d} * Q_{j}\right)\right\}
$$




\section{Results and Discussion}

The empirical results of the study first describe the level of economic efficiency through economic profitability and DRC ratios and competitiveness through private profitability and PCR ratio of Basmati and IRRI rice production systems of the Punjab, during the 1995-96 to 2004-05 period using average farmer cost of production data..

The completed Policy Analysis Matrix in (Table 2) shows the effects of policies on the relative competitiveness of Basmati rice. A negative divergence between private and social profit implies that the net effect of policy intervention is to reduce profitability of Basmati production in Pakistan's Punjab. A removal of policy distortions would substantially increase profitability. The negative output transfers in Basmati production were caused mainly by disprotection by the government's prevailing policies. Basmati rice farmers receive lower revenue than they would have done in the absence of policy distortions. With a minor adjustment in the nominal rates of protection it can be produced with positive private returns and the Basmati production system would become competitive.

Table-2: Results of Policy Analysis Matrix for Basmati Rice Production System

\begin{tabular}{lcccc}
\hline & Revenue & \multicolumn{2}{c}{ Costs } & Profits \\
\hline & & $\begin{array}{c}\text { Tradable } \\
\text { Inputs }\end{array}$ & $\begin{array}{c}\text { Domestic } \\
\text { Factors }\end{array}$ \\
\hline Valued at Private prices & 7320 & 2735 & 5236 & -651 \\
Valued at Social prices & 14228 & 2921 & 6266 & 5041 \\
Divergence & -6908 & -185 & -1031 & -5693 \\
\hline
\end{tabular}

At the margin, positive social profit and the DRC ratio were less than unity implying that the Basmati production system uses scarce resources efficiently (Table-3). The DRC for the Basmati rice Production system was 0.56 . This indicates that Basmati production systems had strong economic efficiency in the use of domestic resources which exhibit comparative advantage and indicated that the crop is potentially very beneficial to Pakistan in term of DRC per unit of foreign exchange earned. On the other hand in the PAM table, the competitiveness of a system is measured by the private profitability (D) or Private Cost Ratio (PCR). Based on information given in Table-3, the PCR of Basmati production was 1.14, which implies that system lacks competitiveness at the current level of 
technology and policy intervention. The ratio formed to measure output transfers is called the Nominal Protection Coefficient on Output (NPCO). The NPCO and EPC for Basmati were 0.52 and 0.41, respectively, on an average for the entire period under analysis. Low or less than unity NPCO and EPC indicates that the price structure discriminates or provides relative disincentives for growing this crop, and this conclusion is reinforced by negative private profitability for average farmers in Pakistan's Punjab. In term of policy implications, the estimates of NPC, EPC and DRC reveal that with the removal of distortions in output and input markets under trade liberalization, the growers of basmati rice are likely to gain and the country is likely to benefit more in producing Basmati rice. The Nominal Protection Coefficient on Input (NPCI) for the Basmati production system was less than 1 (0.94) which indicates that the policies reduce input costs. This indicates that the Basmati production system was slightly subsidized by the policy on tradable inputs but this does not offer any important offset to the overall disprotection for Basmati rice production as the result demonstrates that Effective Protection Coefficient (EPC) remained substantially less than unity (0.41). These results imply that there was significant disprotection from the state to the Basmati production system on value added.

Table-3: Competitiveness and Economic Efficiency Indicators for Basmati Production System

\begin{tabular}{|c|c|c|c|}
\hline Indicators & $\begin{array}{c}\text { Average } \\
1995-96 \text { to } \\
1999-00\end{array}$ & $\begin{array}{c}\text { Average } \\
2000-01 \text { to } \\
2004-05\end{array}$ & $\begin{array}{c}\text { Average } \\
1995-96 \text { to } \\
2004-05 \\
\end{array}$ \\
\hline $\begin{array}{l}\text { Nominal Protection } \\
\text { Coefficient (NPCO) on } \\
\text { Output }\end{array}$ & 0.50 & 0.53 & 0.52 \\
\hline $\begin{array}{l}\text { Nominal Protection } \\
\text { Coefficient (NPCI) on Input }\end{array}$ & 0.94 & 0.96 & 0.94 \\
\hline $\begin{array}{l}\text { Effective Protection } \\
\text { Coefficient (EPC) }\end{array}$ & 0.42 & 0.41 & 0.41 \\
\hline $\begin{array}{l}\text { Domestic Resource Cost } \\
\text { (DRC) }\end{array}$ & 0.51 & 0.61 & 0.56 \\
\hline Private Cost Ratio (PCR) & 1.03 & 1.25 & 1.14 \\
\hline
\end{tabular}

The Policy Analysis Matrix in Table-4 shows the effects of policies on relative competitiveness of IRRI production in Pakistan's Punjab. A negative divergence between private and social profit implies that the net effect of policy intervention is to reduce profitability of IRRI production at the farm level. A removal of policy distortions would increase profitability to some 
extent. The negative output transfers were caused mainly by disprotection policies.

Table-4: Results of Policy Analysis Matrix for IRRI Rice Production System

\begin{tabular}{lcccc}
\hline & Revenue & \multicolumn{2}{c}{ Costs } & Profits \\
\hline & & $\begin{array}{c}\text { Tradable } \\
\text { Inputs }\end{array}$ & $\begin{array}{c}\text { Domestic } \\
\text { Factors }\end{array}$ \\
\hline Valued at Private prices & 5709 & 2553 & 4365 & -1209 \\
Valued at Social prices & 6981 & 2963 & 4568 & -550 \\
Divergence & -1272 & -410 & -202 & -660 \\
\hline
\end{tabular}

Based on the information in Table-5, average economic efficiency indicators for the IRRI rice production system was 1.20 for the whole period under review. In other words, the IRRI production system shows negative social profits: a DRC of 1.20 indicates that IRRI production lacks economic efficiency in the use of domestic resources and IRRI production in Pakistan's Punjab seems to be in a situation of comparative disadvantage. The determination of profit actually received by farmers is a straightforward and important initial result of the PAM approach. In the PAM Table-5, the competitiveness of a system is measured by the private profitability (D) or Private Cost Ratio (PCR). The IRRI production system demonstrates a lack of competitiveness at the current level of technology and prices prevailing at the farmer level because the PCR remained greater than unity (Table-5).

The ratio formed to measure output transfers is called the Nominal Protection Coefficient on Output (NPCO). The average NPCO for the entire period under analysis for IRRI rice was 0.82 , which indicates that IRRI rice farmers received lower prices than they would have received facing world prices or that the system was disprotected.

The Effective Protection Coefficient (EPC) shows the joint effect of policy transfers affecting both tradable inputs and tradable outputs. The EPC for IRRI production systems was 0.82 , which implies that there was overall disprotection from the policy on value added. On the input side, the average Nominal Protection Coefficient on Input (NPCI) was less than $1(0.87)$ for the IRRI production system. This shows that the policy regime favors farmers and reduces the cost of tradable inputs to some extent, but this does not offer any important offset to the overall disprotection that exists for the IRRI production system of Punjab. The results imply that 
Punjab must strive to increase competitiveness and economic efficiency of the IRRI production system through increasing productivity, farm level profitability and resource use efficiency by adequate policy incentives.

Table-5: Competitiveness and Economic Efficiency Indicators for IRRI Production System

\begin{tabular}{lccc}
\hline \multicolumn{1}{c}{ Indicators } & $\begin{array}{c}\text { Average } \\
\mathbf{1 9 9 5 - 9 6} \text { to } \\
\mathbf{1 9 9 9 - 0 0}\end{array}$ & $\begin{array}{c}\text { Average } \\
\mathbf{2 0 0 0 - 0 1} \\
\mathbf{2 0 0 4 - 0 5}\end{array}$ & $\begin{array}{c}\text { Average } \\
\mathbf{1 9 9 5 - 9 6} \\
\mathbf{2 0 0 4 - 0 5}\end{array}$ \\
\hline $\begin{array}{l}\text { Nominal Protection Coefficient } \\
\text { (NPC) on Output }\end{array}$ & 0.69 & 0.96 & 0.82 \\
$\begin{array}{l}\text { Nominal Protection Coefficient } \\
\text { (NPC) on Input (I) }\end{array}$ & 0.87 & 0.87 & 0.87 \\
$\begin{array}{l}\text { Effective Protection Coefficient } \\
\text { (EPC) }\end{array}$ & 0.59 & 1.06 & 0.82 \\
$\begin{array}{l}\text { Domestic Resource Cost (DRC) } \\
\text { Private Cost Ratio (PCR) }\end{array}$ & 0.88 & 1.51 & 1.20 \\
\hline
\end{tabular}

\section{Conclusions}

A mixed picture arises from analyzing the competitiveness and economic efficiency in the rice sector of Pakistan's Punjab through the period under analysis. The Basmati production system was economically efficient and maintained a comparative advantage, but the prevailing price structure discriminates against growing this crop as shown by negative private profitability showing a lack of competitiveness at the farm level. It also expresses the need for the removal of policy distortions to increase the incentives for growers to expand production of an economically advantageous export commodity. Since trade liberalization implies that the market will determine output prices, both basmati growers and the country can benefit.

The IRRI rice production system also exhibits a lack of competitiveness at the farm level because of negative private profitability, An analysis of economic efficiency though DRC implies that the system is not economically efficient in the use of scarce domestic resources which indicates a situation of comparative disadvantage. The estimates of IRRI rice reveals that under trade liberalization, the prospect of IRRI being a major export crop seems to be somewhat gloomy for Pakistan's Punjab. To attain 
economic efficiency in IRRI rice and to sustain its traditional status as an export item of the country, there is an urgent need to increase crop productivity and minimize costs of production. Costs of production can be reduced by decreasing exports incidentals and processing costs incurred from farmgate to export destinations, through adequate policy incentives. Output transfers in the production systems of both IRRI and Basmati were negative and considerably different. The extent of the policy distortion is higher in Basmati production as compared to IRRI rice production. 


\section{References}

Ahmed, S and Roger P. Martini1, 2000, "Agricultural Policy Analysis in Pakistan: Illustrations in the use of the Policy Analysis Matrix" Centre for Management and Economic Research, Lahore University of Management Sciences, Pakistan

Appleyard, D., 1987, "Comparative Advantage of Agricultural Production System and its Policy Implication in Pakistan”, Economic and Social Development Paper No. 68. Rome: Food and Agricultural Organization of the United Nations.

Bruno, M. (1972). "Domestic Resource Costs and Effective Protection: Clarification and Synthesis," Journal of Political Economy, vol. 80, pp. 16-33.

Chaudhry M. G., and N.N. Kayani 1991 "Implicit Taxation of Pakistan's Agriculture: An Analysis of the Commodity and Input Prices" The Pakistan Development Review, Volume 30. No. 3.

Faruqee, R., 1995, "Structural and Policy Reforms for Agricultural Growth: The Case for Pakistan", Agricultural and Natural Resource Division, The World Bank, Washington.

Gonzales, L.A., 1984, "Philippines Agricultural Diversification: A Regional Economic Comparative Advantage Analysis”, Final Report submitted to $\mathrm{ADB}$ as a component of a report on the assessment of food demand-supply Prospects and related strategies for developing member countries of ADB, International Food Policy Research Institute, Washington, D.C.

Gonzales, L.A., F. Kasryno, N. D. Perez and M. W. Rosegrant, 1993, "Economic Incentives and Comparative Advantage in Indonesian Food Crop Production”, Research Report 93, International Food Policy Research Institute, Washington, D.C.

Government of Pakistan, 1995-96, 2000-01, 2005-06, "Economic Survey", Economic Advisor's Wing, Finance Division, Ministry of Finance, Islamabad.

Government of Pakistan, 1995-96, 2000-01, 2004-05, "Agricultural Statistics of Pakistan”, Economic Wing, Ministry of Food Agriculture and Livestock (MINFAL), Islamabad. 
Government of Pakistan, 1996-97, 2000-01, 2003-04, 2004-05, CBR Year Book, Revenue Division, Central Board of Revenue (CBR), Islamabad.

Government of Pakistan, 1996-97, 1998-99, 2000-2001, 2000-03, 2005-06, Support Price Policy for Rice (Paddy) Agricultural Prices Commission (APCOM), Islamabad

Hussain M. F., S. Anwar and Z. Hussain., 2006, "Economics of Sugarcane Production in Pakistan: A Price Risk Analysis" International Journal of Finance and Economics Issue 4 (2006), http://www.eurojournals.com/finance.htm

Kahn, N. P., 2001 "Comparative advantage of Wheat Production in Pakistan and its Policy Implications" Pakistan Journal of Agricultural Economics, Vol. No. 2

Kahn, N. P., and R. A. Hussain 2004 "Comparative advantage of Wheat Production in Pakistan and its Policy Implications" Pakistan Journal of Agricultural Economics, Vo1. 5 No. 1

Krueger, Anne 0.(1966). "Some Economic Costs of Exchange Control: the Turkish case," Journal of Political Economy, vol. 74, pp. 48-62.

Krueger, Anne 0.(1972). "Evaluating Restrictionist Trade Regimes: Theory and Measurement," Journal of Political Economy, vol. 80, pp. 4862 .

Masters, W. A., and A. Winter-Nelson, 1995, "Measuring the Comparative Advantage of Agricultural Activities: Domestic Resource Costs and the Social Cost-Benefit Ratio." American Journal of Agricultural Economics, Vol. 77, pp 243-50.

Monke, E. and S.R. Pearson, 1989, The Policy Analysis Matrix for Agricultural Development. Ithaca, N.Y., U.S.A. Cornell University Press.

Salinger, L., 1997, "Comparative Advantage Analysis" A guide to the Developing Agriculture Markets and Agro Enterprises, pp. 01-120, World Bank, Washington DC.

Warr, P.G., 1994, "Comparative and competitive advantage" Asia-Pacific Economic Literature Vol. 8, No. 2, pp 1-14. 